\title{
A Tricotomic Examination of the Planning School Learning School, and Positioning School Relative to Achieving Optimal Financial Performance in Discontinuous Environmental Turbulence Levels
}

\author{
Dr. Dan Kipley \\ School of Business and Management, Azusa Pacific University \\ PO Box 7000, Azusa, CA. 91702 \\ Tel: 1-626-815-6000Ｅ-mail: dkipley@apu.edu \\ Dr. Alfred O. Lewis \\ Department of Business, Montreat College \\ P.O. Box 1267, Montreat, NC. 28757 \\ Tel: 1-828-669-8011Ｅ-mail: alewis@montreat.ed
}

\begin{abstract}
We present a synthesis of the general methodologies of the Planning School, Learning School, and the Positioning School of strategic formulation which are the most commonly used by academia, research and industry strategic planning. We review the literature from each discipline on these concepts and propose that the cognitive and calculative capabilities intrinsic to the Ansoffian Planning School is the most effective when planning and formulating strategy to achieve optimal financial performance with firms competing in discontinuous levels of environmental turbulence.
\end{abstract}

Keywords: Planning School, Learning School, Positioning School, Ansoff, Strategic Success Paradigm 


\section{Background}

Chaffee (1985) asserts that strategy is multidimensional, situational, and dynamic, but it suffers from the problem of three distinct and in some ways conflicting views on strategy. In this examination we will review three schools of strategy and ask the question; Planning School, Learning School, or Positioning School? Which one should firms, strategic planners, and academia use when formulating strategy?

In answering this question it must be acknowledged that there has been an ongoing, frequently heated debate concerning which functional area is most effective in the field of strategic planning and such debates have included numerous studies supporting one view over the others as well as a suggestion of a trilateral combination of the three.

In the last half century there has been a trend of increasing turbulence in the business environment. Firms are now subject to rapid, discontinuous changes that have become amplified due to the advancements in technology and in the minds of managers, have awakened the real threat and/or possibility that their industry will be the one that is affected by an unseen, undetected, disruptive technology.

Despite claims from some critics that formalized strategic planning is impossible given these environmental discontinuities, there is evidence from the corporate sector that formalized strategic planning is still relevant in the corporate sector (Grant, Romanelli, 2003).

We will examine each of the candidate's methodologies with the objective to determine if a gap exists in their methodologies which limits their effectiveness in the requisite strategic planning formulation, given the conditions of high environmental turbulence.

Specifically, our core thesis is as follows, we argue that strategic formulation in high levels of environmental turbulence must follow formal planning with significance for strategic learning or strategic posture planning, thus accounting for the novelty, unpredictability, and complexity of the environment.

By identifying the conditions associated with high turbulence, juxtapose the requisite competencies necessary for a firm's successful competition and identifying the disciplined strengths of each school; a comparative analysis is then performed to determine which school's strength's are best in conditions of high turbulence.

\section{Taxonomy of the Strategic Schools}

\subsection{The Planning School}

The Planning School views strategic formulation as a formal process in which a thorough set of procedures are followed from which derives a situation analysis in order to formulate the appropriate strategy. Critics argue that the Planning School can become too static and that there is a risk of 'groupthink'. Additionally, concerns of environmental prediction are difficult and that it is driven from top-down allowing little or no subordinate input.

The need for a systematic process of strategic formulation which embraces the firm's vision and creativity permitting a greater flexibility of strategic decisions in response to the 
environmental surprises has been supported by (Burgelman and Grove, 1996; Eisenhardt, 1989).

The Ansoffian Strategic Planning model, which we will use as our candidate model representing the Planning School, adds dynamism to its functionality in three forms; Strategic Learning, Strategic Posture Management, and a robust system of environmental scanning, thus answering the critic's claims of invariability and environmental predictability.

The Planning School gains support from such advocates as (e.g. Ansoff, 1965; Andrews, 1971; Ansoff, Antoniou and Lewis, 2004; King \& Cleland, 1978).

\subsection{The Learning School}

The Learning School approach to strategic formulation considers both adaptability and incrementalism allowing for the emergent process of management to incorporate the 'lessons learned' methodology when formulating strategy. This approach treats strategic formulation as an ongoing process of conceptual design favoring logical incrementalism over design especially in unstable environments (Mintzberg, 1991, 1994).

The Learning School views the speed and change of business to be so dynamic and fast that firm can't afford to pause for formal planning, viewing Planning Strategy as rigid and inflexible and therefore by following such a school, would make your strategy outdated before it was produced.

Synonyms also include emergent strategy (a pattern of action over time that is not driven by central intention) prescriptive, incremental, adaptive, and complex learning process (Lindblom, 1959; Mintzberg, 1978, 1990; Quinn, 1980).

Critics of the Learning School claim that this methodology is a modest improvement over 'muddling through' triggering both strategic drift and 'oscillation' from one strategy to another, to yet another, continually searching for the optimal strategy for the firm.

Critics also assert that the Learning School of Strategic formulation is of little use in stable environmental conditions and less use during a crisis, the practicality of making incremental steps when facing an immediate crisis is unwise and extremely costly.

Those who support the Learning School of strategic formulation are (Mintzberg, 1976; Quinn, 1980; Burgelman, 1982; Prahalad \& Hamel, 1996, Mintzberg \& Waters, 1982; Pascale (1984).

\subsection{The Positioning School}

The Positioning School is very similar to the Planning School in its approach by providing a systematic way to the formulation of Strategy through an analytical process. However, it differs from the Planning School by centering the Strategic formulation on the business unit within the context of its industry and focuses its strategic planning on extrapolative data using market factors relative to it position juxtaposed its industry. By focusing on the dynamic relationship between enterprise strategy and the industry structure, the Positioning School posits that it is possible to 'select a strategy' based upon the defined position of the firm 


\section{Macrothink}

within the marketplace, derived through analysis of the 'numbers'. To aid managers in assessing their position, the Positioning School has formulated the five forces framework (Figure 1), and the generic strategies (Figure 2), often referred to as management 'decision aids'. These tools are integral when using the Positioning School of strategy in assessing the firm's competitive position relative to the industry (Porter, 1980).

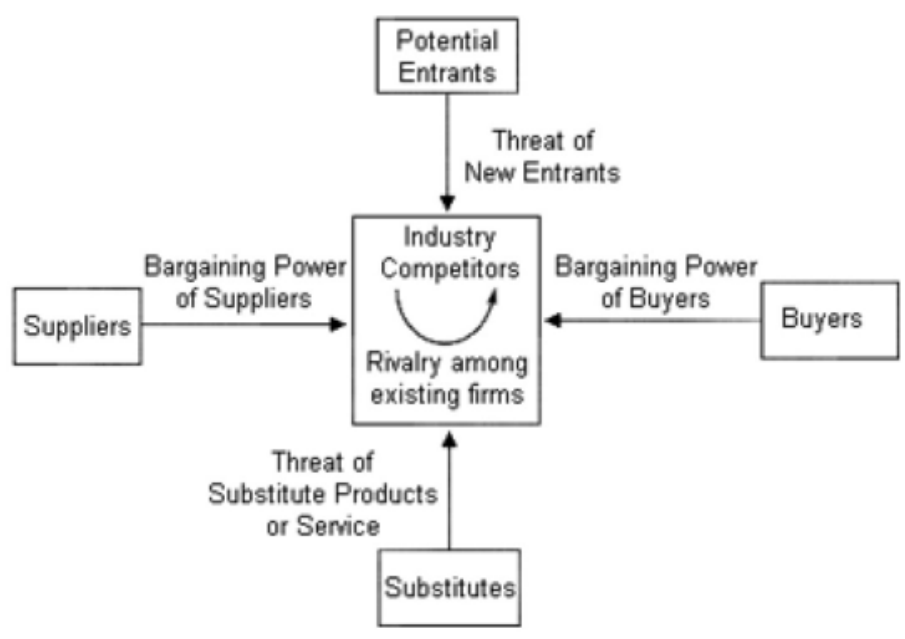

Figure 1. Porter's Five forces Diagram

Critics of the Positioning School assert that when using the generic strategies and five forces, the firm's strategy is reduced to 'generic positions' that are often most appropriate for formalized large, mature industry conditions who formulate their strategy based only on 'running the numbers'.

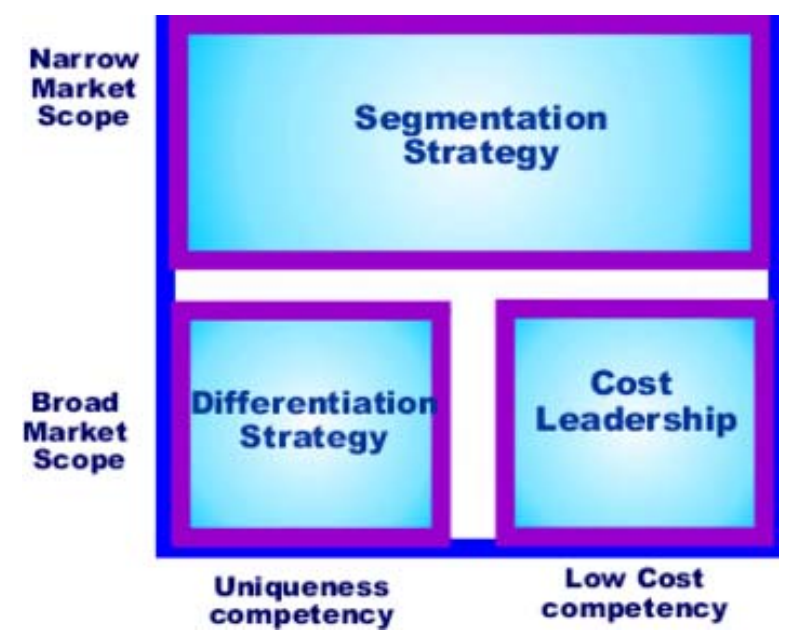

Figure 2. Porter’s Generic Strategies

An additional critical point is that the Positioning School fails to account for the influences of power from stakeholders, governmental pressures and influence, cultural differences and demands, societal elements, effects of internationalization, and does not have an effective 
system for environmental scanning in place.

Michael Porter's book 'Competitive Strategy' (1980) acted as a stimulus in driving the interest behind the Positioning School of thought in strategic formulation, other supporters include; Dees and Davis, 1984; Miller and Dess, 1993; Miller and Friesen, 1986, McNamee and McHugh, 1989.

\section{Typology of Environmental Turbulence}

Ansoff categorized the environment in which firms compete into five distinct and definable turbulence levels (Figure 3) beginning with Level 1, defined as "stable"; within this level the environment has no change and tomorrow will be similar to the present, hence, planning at level 1 is extrapolative. Level 2 is "expanding"; change is slow and incremental, visible, and predictable, planning at level 2 is also extrapolative. Level 3 is "changing”; although change is fast, it is still incremental and fully visible. The first three levels of environmental turbulence are sub-classified by Ansoff as "history driven" in that the future is a logical extension of the historical past and present.

Levels 4 \& 5 are defined as “discontinuous \& surpriseful” by Ansoff; the future is very different from the historical past and past successes do not guarantee future success. Level 4, a major departure from the extrapolative environment, is defined as "discontinuous". In order to be successful a firm must abandon its historical attachment to particular customers, technologies, and/or products that it was accustomed to in level 3 and formulate its strategy with a new set of rules. The challenges that face a firm in level 4 include limited visibility, partial predictability, rapid change and inability for the firm to react to that change within the time required.

Ansoff's final level, Level 5 is described as "surpriseful”; change at this level occurs without notice, without visibility, unpredictable, and extremely rapid. In order for firms to become successful at this level they must be open and flexible to create products and services with advanced innovative technological ideas. Firms whose Strategic Business Areas (SBA) compete globally most likely align within the description of turbulence level 5.

An extension of the definition of Levels 3 -5 environment was provided by (Ansoff et al., 2004) to include "the pace of change, planned and unplanned product obsolescence coupled with the discontinuous rate of change." This increased intensity changes the existing paradigm of firms focusing solely on industry competitors, and creates a new paradigm which includes threats from unrelated industries”.

\section{Discontinuous Environments}

It is reasonable to presume that in low levels of environmental turbulence typified by recurring, forecastable, or predictable visibility (turbulence 1-3), there is insignificant negative influence on strategic planning. A review of studies in the field suggests that, and participating theorists agree, in a sufficiently stable and/or predictable environment (level 1-3); strategy formulation will remain viable after implementation. This view is supported by (Ansoff, 1990) "level 1 aggressiveness is rarely observed in the business environment, but 
is common in the not-for-profit organizations which do not change their products/service unless forced by a threat of their survival”. This concept of visibility and predictability can be carried forward to include levels 2 and 3 as well, noting that the visibility of the future is predictable and therefore viable for implementation.

Therefore for specificity, this review will focus on only those areas of "discontinuous environments", which are indicated by using Ansoff's Environmental Turbulence Scale at level 4 or greater. These areas of focus are indicated by the shaded area the following table and defined as a combined measure of the changeability and predictability of the firm's environment. It is further described and defined by its four characteristics;

\section{Changeability:}

Complexity of the firm's environment - a dual measure of the pervasiveness of the impact of a challenge on various parts of the firm, as well as the frequency of occurrence of challenges.

Relative novelty of the successive challenges which the firm encounters in the environment a measure of the extent to which knowledge gained from experience can be extrapolated to responses to new challenges.

\section{Predictability:}

Rapidity of change. The ratio of the speed with which challenges evolve in the environment and the speed of the firm's response.

Visibility of the future which assesses the adequacy and the timeliness of information about the future (Ansoff, 1990).

\begin{tabular}{|c|c|c|c|c|c|c|}
\hline \multirow{5}{*}{ 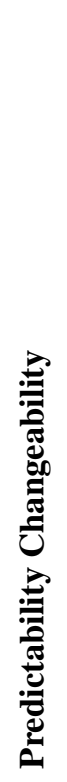 } & $\begin{array}{l}\text { Environmental } \\
\text { turbulence }\end{array}$ & Repetitive & Expanding & Changing & Discontinuous & Surprising \\
\hline & \multirow{2}{*}{$\begin{array}{l}\text { Complexity } \\
\text { Familiarity of } \\
\text { events }\end{array}$} & $\begin{array}{l}\text { National } \\
\text { Economic }\end{array}$ & * & $\begin{array}{l}\text { Regional } \\
\text { Technological }\end{array}$ & $*$ & $\begin{array}{l}\text { Global } \\
\text { Socio-Political } \\
\end{array}$ \\
\hline & & Familiar & Extrapolable & & $\begin{array}{l}\text { Discontinuous } \\
\text { Familiar }\end{array}$ & $\begin{array}{l}\text { Discontinuous } \\
\text { Novel }\end{array}$ \\
\hline & $\begin{array}{l}\text { Rapidity of } \\
\text { Change }\end{array}$ & $\begin{array}{l}\text { Slower } \\
\text { than } \\
\text { response }\end{array}$ & & $\begin{array}{l}\text { Comparable } \\
\text { to response }\end{array}$ & & $\begin{array}{l}\text { Faster than } \\
\text { response }\end{array}$ \\
\hline & $\begin{array}{l}\text { Visibility of } \\
\text { future }\end{array}$ & Recurring & Forecastable & Predictable & $\begin{array}{l}\text { Partially } \\
\text { Predictable }\end{array}$ & $\begin{array}{l}\text { Unpredictable } \\
\text { surprises }\end{array}$ \\
\hline & $\begin{array}{l}\text { Turbulence } \\
\text { Level }\end{array}$ & 3 & 1 & 4 & & 2 \\
\hline
\end{tabular}

Figure 3. Level 4 \& 5 environments are unstable, unpredictable, rapidly changing, 
discontinuous, novel, and surprising.

\section{Assessment of the Planning School}

As mentioned, the Planning School views strategic formulation as a formal process, the sequence begins with the analysis of situations, to formulation, and execution of the strategy. It has been well documented through research that an appropriate analysis of the firm's environmental turbulence level is a critical component when planning the firm's strategy and cautions managers that misalignment of the environmental turbulence level with the firm's strategy can cause strategic suboptimization leading to poor financial performance or loss of market share. Simon (1993) states in his study that 'effective strategic planning calls for anticipating the future, scanning the environment for present and prospective competitors and novelties, and developing skills to generate alternatives in order to implement new plans'.

It is understandable that theorists of the Planning school feel that the increased level of environmental turbulence has the potential to create an atmosphere too complex for cognitive development, consequently increasing the need for a formalized strategic planning process.

The Planning School anticipates a calculative rationality as its basis for strategic management, demanding both greater cognitive and calculative capabilities in planning and formulation. Walter (1980) states;

"The proponents of synoptic formulation...do not even recognize let alone attempt to respond to the imperatives deriving from an acceptance of logical incrementalism”.

It is therefore critical that firms recognize their turbulence level and plan strategically for the appropriate level.

Ansoff's Strategic Success Paradigm states that 'for optimal financial success, the aggressiveness of the firm's strategy must match the environmental turbulence level' (Ansoff, 1965). This portion of the Strategic Success Paradigm was borrowed from the concept of organization-environment matching found in the Requisite Variety Theorem by W.R. Ashby which states, 'in order to succeed in its environment, an organization must match the complexity of its response to the complexity of the environment' (Ashby, 1956). Ansoff considered formal, logical, comprehensive planning to be beneficial in all types of environmental conditions not simply high levels of discontinuity. Camillus supports Ansoff when he stated that the 'single most important common thread that runs through all synoptic formal approaches is the reliance on an analytical framework that is perceived to be logical and comprehensive' (Camillus, 1982).

Brews and Hunt conducted a study that further validate Ansoff and formalized planning as the driving force behind the strategic process, 'this study concludes environment does not moderate the type of planning firms pursue, external firm performance and internal planning performance are clearly associated with formal, specific planning, regardless of environment' (Brews, Hunt, 1999).

As indicated in Figure 1, Ansoff describes five environmental turbulence levels (ETL); the Ansoffian model has complementary functional components which allow firms to formulate a 
strategy which is most effective for each given ETL; the Strategic Diagnosis, and Strategic Posture Planning (SPP).

The Strategic Diagnosis component helps to identify three critical areas necessary for strategic planning; first, whether a shift is likely to occur in the environmental turbulence level. Second, the profile of the management capability required for the ETL, finally, the type of Strategic Planning System most appropriate to use to optimize the firms success in the new level.

Strategic Posture Planning (SPP) enables the firm to visualize the probable future ETL and to create and pursue the appropriate future success strategy for the firm by accounting for the risks inherent to such decisions. Additionally, SPP forms the strategy the firm will pursue, identifies which capabilities it must develop to support its strategy, and the level of strategic investment the firm will need to dedicate for optimal success.

The Ansoffian model of strategic planning with the Strategic Diagnosis and Strategic Posture Planning components provide the tools necessary for a firm to formulate a strategy in any of the described turbulence levels thus enabling a firm the ability to create a sustainable competitive advantage.

One major point of contention with the Planning School claimed by the proponents of the Learning School is that firm's adapting the Planning School has a loss of flexibility when making strategy planning explicit. The Learning School contends that for strategy to 'function' it must do so only in periods of stability and predictability and that using explicit strategy is similar to a set of 'myopic obstacles' for management, preventing them from identifying strategic options available to the firm. This is a recurring theme observed throughout the literature that reviews Learning vs. Planning in which the proponents of the Learning School view "explicit strategy" as a limitation to the "learning process" and recommend that in order for the firm to become successful it requires both the "learning and the evolving" that is resultant of the learning process. Mintzberg cites Kiesler's study into cognitive psychology as further validation and support of this learning school position.

"there is in fact, evidence from the laboratories of cognitive psychology that the explication of a strategy - even having someone articulate ...locks it in, breeding a resistance to later change" (Keisler, 1971).

The Planning school's rebuttal launched by Ansoff points out those successful practitioners of strategic planning use mechanisms for strategic controls which have built in periodic reviews of the current strategic progress. If necessary, revisions are made to the existing strategy to account for and adapt to changing environmental influences.

The research conducted by Brews and Hunt supports Ansoff's claim that performance of strategy is not adversely affected by explicit strategic planning;

"the findings clearly show that as environmental instability grows, so does flexibility...at the very least, planning specificity is not systematically associated with inflexibility - the "rigidity hypothesis" in not supported" (Brew, Hunt, 1999). 
Although the SPP may seem rigid preventing adjustments initiated by a surprise event, Ansoff has added components which enable the firm to make timely responses to surprising threats and opportunities, Issue Management and Surprise Management are two functional tools that deal with surpriseful events which may be overlooked by the SPP. This expands the functionality allowing the Ansoffian Strategic Planning Model the structure of formality and the dynamism of adaptability (Ansoff, Antoniou and Lewis, 2004; Antoniou, Sullivan, 2006).

\section{Assessment of the Learning School}

The Learning School supports a position that is opposed to formal planning and is in favor of an adhocracy approach of trial and error. A statement made by Henry Mintzberg, the learning schools main proponent, on his position regarding the need for formalized strategic planning is clear, "strategic planning is ...impossible unless the environment is stable and predictable" and that firms that do so are wasting their time and energy.

Mintzberg contends that formal planning is only acceptable and functional in environmental conditions that are controllable and forecastable and in which data can be extrapolated for use in future planning. His position on high levels of environmental turbulence is that such times demand logical incrementalism as the best solution for a firm’s planning.

This view is a fundamental principle of the learning school however there are at least two problems with extrapolation for future planning. Levinthal and March (1993) described two major learning mechanisms that affect learning from experience. The first is "simplification" of the learning processes which seek to "simplify experiences" and to minimize interactions and restrict the effects of time and space.

Simple stated it is human nature to 'compress' events into simplified experiences for ease of iteration; this compression naturally deletes all of the relevant 'facts' necessary to the historical event. Secondly, is "specialization" of the learning processes to focus attention and narrow the competence.

The fundamental flaw with Levinthal, March, and Mintzberg is that experience becomes clouded by the complexity of historical events, temporal alignment of the events, and inconsistencies of human memory.

Considering that extrapolation derives its planning from history and as previously indicated, and acknowledging that our experiences become clouded with the complexity of history, Mintzberg's strategic planning based on extrapolation formulation, would simply be an inhibited plan.

Brews and Hunt (1999) add depth to this discussion by revisiting the dichotomy that exists between the two schools of thought and conducted research gathering quantitative data to determine if claims made by the proponents of the competing schools of strategic planning are justified. Their research revealed that those claims made in support of the learning school on strategy formulation, in actuality found that firms represented an "intended" strategy as their desired plan but logical incrementalism, especially in unstable environments is favorable. Due to the unstable environments, incremental internal and external forces alter the intended 
strategy through “emergence” and as a result, firm’s had a "Deliberate” strategy (Brews and Hunt, 1999).

Strategy must have continuity; incrementalism creates discontinuity and misdirection making it difficult for a firm to grasp what its strategy. If, by the end of the day, you don't have something distinctive and your organization is unsure as to what need it fulfills to be different from its rivals, it will be difficult to maintain continuity within your firm and with your customers.

Mintzberg states that the problems firm have in making strategies explicit is that they (firms) needs to view strategy formulation as a "learning process" and managers are unable to accomplish this learning process with the "myopic obstacles" of the design school focus (Mintzberg,1990). He further argues, as a follow-up to Lindblom (1959), “ when environments are not complex or turbulent, planning will, at worst, do no harm; but, under high complexity, turbulence planning no longer works, and managers must return to "intuitive managing."

As such, Mintzberg's incrementalism approach encourages managers to use the hunt-and-peck method of finding a strategy; try something, see if it works, then proceed to the next.

The difficulty with this form of "cognitive simplification" is that it places limits on the firms' strategic decision planning by limiting the relevant, valuable, and alternative solutions and reduces the probability of the appropriate strategic formulation being implemented. The firm without a formal strategy will try anything including the same as its rivals; in that case, the probability of optimal financial success will be remote (Porter, 1980).

It is fairly evidenced and unanimously agreed upon that the time span aspect of the temporal dimension, frequency, and rapidity of change of technological advances significantly heightens the level of environmental turbulence and that by making small, incremental, reactive steps in strategic positioning, is extremely unwise (Ansoff, 1991).

This form of "reactive management" is not only ineffective but also costly to firms. In a study conducted by Ansoff and McDonnell (1990), there is evidence provided that indicates the loss of revenue and one could postulate, loss of market position to a firm due to time of indecision, countermeasures taken, and costs to arrest the threat.

Is there a relationship between the learning schools 'incrementalism approach' to planning and "reactive management"? Ansoff believes that there is, and states....

"there are many historical cases of such firms which refused to recognize the "writing on the wall" of the impact of a novel technology, or a change in consumer preferences, or of a change in major political realignment” (Ansoff ,1990)

In Figure 4, the graph depicts cost impact to a firm due to delayed responses associated to reactive management decisions. In reactive management, the time delay from the "rational trigger point" to the "delayed trigger point" may be attributed to the effects of “incrementalism” as indicated in Figure 4. Ansoff, McDonnell (1990). 


\section{Macrothink}

Reactive management is an ex-post approach to addressing environmental disturbances. This management approach most closely aligns, in principle, with the "learning school or emergent school supported by Mintzberg.

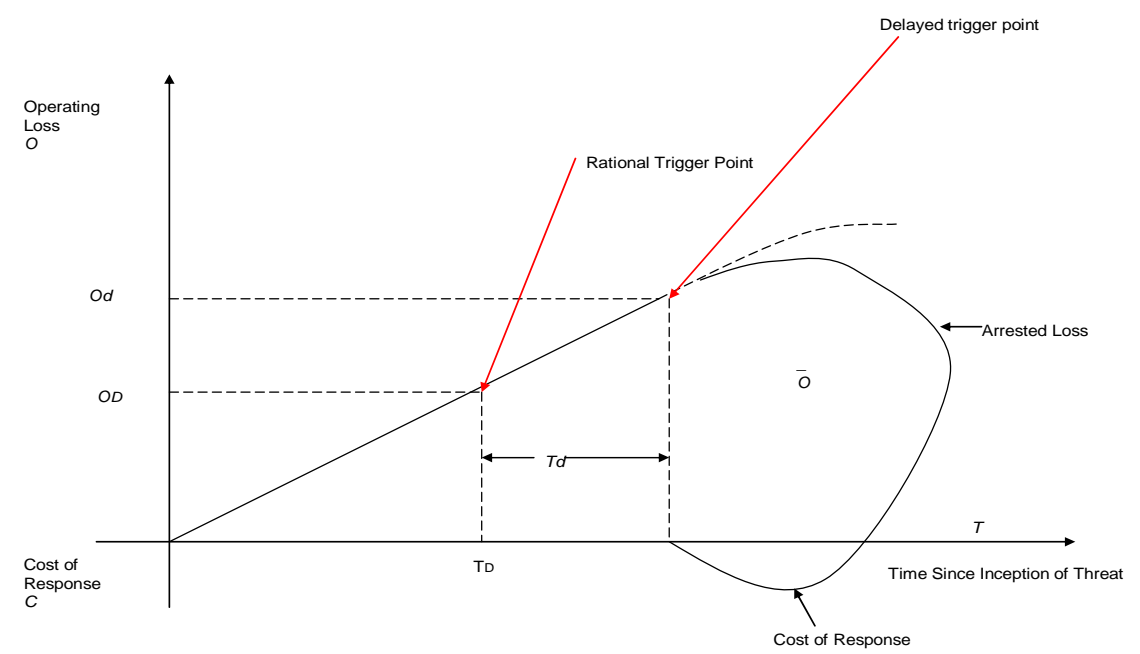

Fig. 4 Reactive Management

Planning School's forecasting strengths enables it to identify threats and to address them well in advance, reducing the procrastination time, and thus eliminating substantial costs to the firm.

As indicated in Figure 5, when the reaction time is shortened during the planning phase, the procrastination time is reduced and consequently so is the potential loss to the firm.

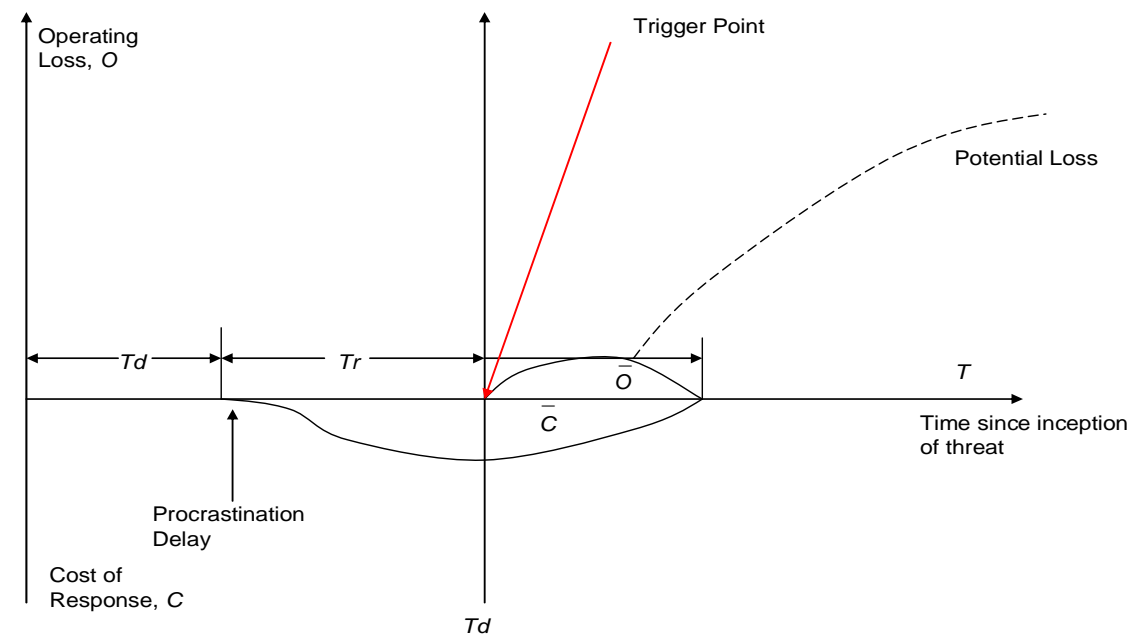

Fig 5. Planned Management 
De Geus (1996), the former head of Shell planning, suggests one possible approach is to use single-point forecasting with a range of possible outcomes that provide multiple planning scenarios. This approach to Strategic Planning offers alternative views of the future in the form of unique combinations of the key environmental drivers and has been used by the primary leader in scenario planning within the corporate sector, Shell. De Geus supports the process of strategic planning when he says,' the primary contribution of scenario planning is not so much the creation of strategic plans, as establishing a process for organization learning and for decision makers to communicate their knowledge about business'.

\section{Assessment of the Positioning School}

As previously mentioned, the Positioning School is very similar to the Planning School in its reflection of strategic formulation. Porter (1980) mentions the value of the explicit when stating, 'the emphasis being placed on strategic planning today in firms...reflects the proposition that there are significant benefits to gain through an explicit process of formulating strategy, to insure...policies, functional departments are coordinated.'

The view, however, that the positioning school holds is in effect one of strategic formulation with regards only to the competition of the firm in its microenvironment. As we have discussed previously, the environment is more dynamic than simply the industry competitors, factors that also impact strategy formulation include social, cultural, technological, global, legal, and managerial. All must be considered when formulating the firm's strategy in an effort to achieve the maximum financial gain.

\section{Environmental Scanning}

The consequences of inadequate environmental scanning are provided in the two following vignettes; the first is a firm that follows the positioning school of strategic formulation, viewing cost vs. differentiation and following the five forces model. The second firm, equally successful but was ill-prepared for a cultural shift in consumer buying preferences. The result was both firms were myopic in the use of the appropriate environmental scanning tools.

The following Remarks were made by Charles Van Horn, President of the International Recording Media Association (IRMA), during IRMA's 12th Annual Technology \& Manufacturing Conference, Oct. 6, 2000, Scottsdale, AZ.

\subsection{Vignette 1 - Encyclopedia Britannica}

In 1990, the sales volume of the encyclopedia sets had reached about $\$ 650$ million dollars. Encyclopedia Britannica enjoyed dominant market share, steady growth, generous margins, and a stable brand name. All of the elements that the positioning school instructs a firm to pursue. However, in 1991 sales fell as a result of an inexpensive disc, a disruptive technology of the late-twentieth century information revolution - the CD-ROM.

Microsoft released the $\mathrm{CD}$, which cost about $\$ 1.50$ under the brand name Encarta and although it retailed for as much as $\$ 70$, was usually included in the software bundle on new computers to encourage sales. Britannica costs however, were considerably higher, nearly 
\$250 dollars for manufacturing plus nearly $\$ 600$ for commissions on a product retailing for as much as 30 times that of the CD.

Results of the poorly equipped and ill-prepared environmental scanning from the Britannica analysts viewed the CD-ROM as a child's toy, one step above video games, and not a threat to their industry; this in part was due to managerial filtering of the threat assessment. Adding insult to injury, the managers decided to watch from the sidelines instead of getting into the game. By the time, executives at the encyclopedia publishing house decided to act, it was too late. Sales had collapsed, the sales force no longer believed in the product, the competition had taken over, and the consumer had gone elsewhere. In 1995, the Benton Foundation put the company up for sale. For nearly eighteen months, they tried to find a buyer and finally they ended up selling the company for less than one half of book value.

\subsection{Vignette 2 - Atkins Diet/ Continental Bakeries}

The executives at Interstate Bakeries were faced with the realization that they were competing in an overcapacity industry that was experiencing increasing raw material, increased labor and health benefits, and declining sales. These signs were all easily Forecastable as they were common throughout the industry. What wasn't Forecastable was the diet craze that was generated by weight-loss guru Dr. Robert Atkins. Atkins claimed that his diet prompted "ketosis," a metabolic state in which fat is burned more efficiently. Many Americans and dieters across the world loved the program's appeal. No longer would they have to obsess about cutting high-fat foods for so-called lean cuisine. They could feast on meat and fats without guilt if they followed the Atkins diet. Bacon, prime rib and cheese were in; Wonder Bread, Twinkies, and cupcakes were out.

While the Atkins diet helped fuel demand for beef, chicken, cheese and other food rich in proteins, the manufacturers of carbohydrate-laden foods, such as Wonder Bread, saw sales fall. Executives at Interstate Bakeries Corp. admitted that they miscalculated in the demands of their customers when confident that the white bread market was never going to change. Consequently, the 77 yr. old company declared bankruptcy shuttering 6 of its 53 bakeries.

The previous examples were provided to illuminate the need for firms to implement a formalized strategic plan which includes those tools necessary to complete an accurate environmental surveillance. Diagnosing the turbulence level is, at best, an imprecise process. However, the benefits to those firms who have implemented a formal system of strategic planning utilizing the tools of environmental scanning is readily observable similar to those risks faced by firms which choose alternative methods or approaches.

\section{Managerial Performance}

Of the three schools of strategic planning studied, only one addressed the subject of managerial behavior which specifically influences performance, the Planning School. Ansoff's model of Strategic Planning focuses on the importance of the firms' managerial capabilities in the areas of its strategic culture or climate, managerial competency, and logistics capabilities and emphasizes that they must also properly match the level of environmental turbulence level for optimal performance to be achieved; when they are 
misaligned, the performance of the firm will be suboptimal.

For example, management whose multivariate capabilities are solely based on experiential wisdom accumulated from and whose decision-making is based on a low degree of information coupling within other functional areas would be less-likely to achieve optimum success in a highly unpredictable, discontinuous environmentally turbulent industry.

A disparity between current and required management competence capabilities produces an identifiable gap caused by the disparity in the environmental turbulence levels in which the firm competes. This gap in cognitive interpretation of the strategic issues, value judgments, and information processing would exceed, with any reliable degree of integrity, the low environmental turbulence level managerial skills set.

Numerous studies support the significance of managerial competencies as it pertains to the firm's strategy-making and strategic performance. The firm's organizational performance is ultimately influenced and guided by the differences in top manager's skills levels and creative talents. Hambrick and Mason (1984), Hambrick (1987), and Norburn and Birley (1988) "Actors (management) are assumed to be intelligent, but their intelligence is local to their position on the landscape (environment)" (March and Simon, 1958; Cyert and March, 1963).

\section{Implications and Conclusions}

In this note we have attempted to address the current ambiguity regarding which concept of strategic formulation optimizes the firm's financial performance in discontinuous levels of environmental turbulence. We have done so by conducting a thorough review and synthesizing the relative strategic literature to which our analysis revealed that there was one preferred school of strategic formulation that provides the optimal results under the given conditions.

Figure 6, aligns the Planning, Positioning, and Learning School on a matrix for a juxtapose comparison of the schools methodologies, highlighting the strengths and weaknesses of each including critic's comments, source of methodologies, and the level of environmental turbulence in which each school's attributes would be most effective.

After reviewing the general methodologies of the Planning, Positioning, and Learning Schools, our conclusions affirm our original core thesis that the Ansoffian method of the Planning School of Strategic Formulation is most effective in achieving optimal financial performance for firms competing in discontinuous levels of environmental turbulence.

Ultimately, cumulative empirical research, based on a solid theoretical framework, is the only way to bring valid evidence to support the question of 'optimal' strategic formulation methodology for a given environmental turbulence level. Our hope is that others will evaluate the conclusions and add to the study with more formal theory and empirical evidence. 


\begin{tabular}{|c|c|c|c|c|c|c|c|}
\hline SCHOOLS & Source & Strategic Formulation & Champions & $\begin{array}{l}\text { Intended } \\
\text { Messages }\end{array}$ & Critcics & $\begin{array}{l}\text { School } \\
\text { Category }\end{array}$ & Level $4>$ Effectiveness \\
\hline Planning & $\begin{array}{l}\text { LAnsolf, } \\
\text { Grove,Eisenhardt, } \\
\text { Andrews, Lewis, King, } \\
\text { Cleland, Sulivan }\end{array}$ & $\begin{array}{l}\text { Formal Process, Deriving } \\
\text { sets of Proceedures, } \\
\text { environmental scanning, } \\
\text { strategic segmentation, } \\
\text { managerial capabities gap } \\
\text { analysis }\end{array}$ & $\begin{array}{l}\text { "Professional" managers, } \\
\text { MBAs, staff experts } \\
\text { (especialy in finance), } \\
\text { consultants, \& government } \\
\text { controllers - especialy in } \\
\text { France and the US }\end{array}$ & Formaize & $\begin{array}{l}\text { Creates 'Groupthink, too } \\
\text { static, top-down driven, } \\
\text { inflexble }\end{array}$ & Prescriptive & $\begin{array}{l}\text { Most effective - } \\
\text { Environmental scanning } \\
\text { proceedures, managerial } \\
\text { assessment, Strategic } \\
\text { Diagnosis, SPP, Issue } \\
\text { Managementi, Surprise } \\
\text { Managemen! }\end{array}$ \\
\hline Positioning & $\begin{array}{l}\text { Porter, Dess, Davis, } \\
\text { Friesen, Miler }\end{array}$ & $\begin{array}{l}\text { Formal Process, Focuses on } \\
\text { business unit within context } \\
\text { of industy - generic } \\
\text { strategies, } 5 \text { forces }\end{array}$ & $\begin{array}{l}\text { As in planning school, } \\
\text { particularty analytical staff } \\
\text { types, consulting } \\
\text { boutiques", \& witers, } \\
\text { especialy in the US }\end{array}$ & $\begin{array}{l}\text { Numbers } \\
\text { driven anaysis }\end{array}$ & $\begin{array}{l}\text { Generic strategles are } \\
\text { designed for formaized } \\
\text { large companies, does } \\
\text { not account for infuence } \\
\text { from stakeholders, govt }\end{array}$ & Prescriptive & $\begin{array}{l}\text { Less Effective - focuses on } \\
\text { positioning the fim within } \\
\text { industry and developing } \\
\text { compettive advantages }\end{array}$ \\
\hline Learning & $\begin{array}{l}\text { Mintzberg, Lincbiom, } \\
\text { M.Cyert, J.G.March, } \\
\text { KE.Weick, J.B. Quinn \& } \\
\text { C.K.Prahlad \& G.Hamel }\end{array}$ & $\begin{array}{l}\text { Adaptability, logical } \\
\text { incrementalism, emergent on } \\
\text { going process }\end{array}$ & $\begin{array}{l}\text { People incined to } \\
\text { experimentation, ambiguly, } \\
\text { adaptabity - especialy in } \\
\text { Japan and Scandinavia }\end{array}$ & Leam & $\begin{array}{l}\text { Nethodology is I itle } \\
\text { better than 'mudaing } \\
\text { through', creates } \\
\text { strategic drit, oscilation, } \\
\text { extremely costly }\end{array}$ & Descriptive & $\begin{array}{l}\text { Not Effective - focus on } \\
\text { adhocracy, trial and error. } \\
\text { simplification and } \\
\text { incrementalism, bases } \\
\text { decisions from extrapolation } \\
\text { of past events }\end{array}$ \\
\hline
\end{tabular}

Figure 6. Planning, Positioning, Learning School’s matrix

\section{References}

Andrews, K. R. (1971). 'The Concept of Corporate Strategy', Dow-Jones Irwin: Homewood IL.

Ansoff, H. I. (1965). 'The firm of the Future', Harvard Business Review, Sept. Oct.

Ansoff, H. I. (1965). Corporate Strategy, McGraw-Hill, New York.

Ansoff, H. I. (1991). 'Critique of Henry Mintzberg's the Design School: Reconsidering the basic premise of Strategic Management’ Strategic Management Journal, Vol. 12, 449-461.

Ansoff, I. \& McDonnell, E. (1990). Implanting Strategic Management (Second ed.) Prentice Hall: New York.

Ansoff, Antoniou \& Lewis, (2004). 'Strategic Management: Introduction to the Ansoffian Approach' - Xanedu Press:Michigan.

Antoniou, P. H. and Sullivan, P.E. (2006). The Igor Ansoff Anthology, BookSurge, LLC.

Ashby, W. R. (1956). 'An Introduction to Cybernetics', Chapman \& Hall: London.

Brews, P.J. and Hunt, M.R. "Learning to plan and planning to learn: Resolving the planning school/learning school debate” Strategic Management Journal, Vol.20: 10, 1999.

Burgelman, R.A. (1982). 'A Model of the Interaction of Strategic Behavior, Corporate Context, and the Concept of Strategy', Academy of Management Review, 8, 1, 61-71.

Burgelman, R. A. and Grove, A. (1996). 'Strategic dissonance', California Management Review, 38 (2).

Camillus, L.C. (1987). Contrasting Planning Systems in high, medium and low Performance Companies. Journal of Management Studies 24 (4), 363-385.

Chaffee, E. (1985). 'Three Models of strategy' Academy of Management Review, 10, (1) 89-98. 
Cyert, R., and March, J. (1963). A Behavioral Theory of the Firm. New Jersey: Prentice Hall. De Geus, A. (1996). 'The Living Company', HBS Press: Boston.

Dess, G.G., and Davis, P. S. (1984). Porter's (1980) Generic Strategies as determinants of Strategic Group membership and Organizational performance. Academy of Management Journal, 27 (3), 467-488.

Eisenhardt, K.M. (1989). 'Making fast strategic decisions in high-velocity environments', Academy of Management Journal, 32, pp.543-559.

Grant, R.M and Romanelli, E. F. (2003). 'Strategic Planning in a Turbulent Environment', Strategic Management Journal, Vol. 24, Iss. 6, 491-517.

Hambrick, D.C. and Mason, P. A., (1984). Upper echelons: The organization as a reflection of its top managers' Academy of Management Review, 9(21), pp. 193-206.

Hambrick, D.C. (1987). The top management team: Key to strategic success, California Management Review, pp.88-108.

Kiesler, C.A. (1971). The Psychology of Commitment: Experiments linking Behavior to Belief, Academic Press: New York.

King, W.R., and Cleland, D.I. (1978). 'Strategic Planning and Policy', Van Nostrand Reinhold: New York.

Levinthal, D.A. and March, J. G. (1993). 'The Myopia of Learning', Strategic Management Journal, Vol.14, 95-112.

Lindblom, C.E. (1959). 'The Science of ‘Muddling Through', Public Administration Review 19: 79-88.

March, J., and Simon, H. (1958). Organizations. New York: John Wiley \& Sons.

Miller, A. and Dess, G. (1993). Assessing Porter's (1980) model in terms of its generalizabilty, accuracy, and simplicity', Journal of Management Studies, 30 (4) 553-585.

McNamee, P. and McHugh, M. Competitive strategies in the clothing industry. Long Range Planning, 22, 4, pp63-71, 1989.

Miller, A., and Friesen, P. (1986). A mathematical model of the adaptive Behavior of Organizations, Journal of Management Studies, 23, 1-25.

Mintzberg, H. (1976). 'Planning on the left side and management on the right', Harvard Business Review, July/Aug.

Norburn, D. and Birley, S. (1988). The top management team and corporate performance, Strategic Management Journal, 9 (3), pp.225-238.

Porter, M.E. (1980). Competitive Strategy, Free Press: New York.

Prahalad, G. and Hamel, C.K. (1996). 'Competing for the Future’, Harvard Business School Press.

Quinn, J.B. (1980). 'Strategies for Change: Logical Incrementalism, Irwin: Homewood, IL.

Simon, H.A. (1993). 'Strategy and Organizational Evolution' Strategic Management Journal, Vol. 14, 131-142. 